\title{
Microfinance Accessibility and Households Improvement through in SHGs: A Empirical Evidence from Tiruvannamali District in Tamilnadu
}

\author{
L. Kuppusamy*., P.Muthaiyan**., V. Sathiyaseelan*** \\ * Research Scholar, Department of Economics, Pondicherry central University, India-605014 \\ ** Professor, Department of Economics, Pondicherry central university, india-605014 \\ *** Research Scholar, Department of Commerce, Pondicherry central university-605014
}

\begin{abstract}
The present study is Evidence on microfinance and household improvement services these days as luck would have it shows a great preference for savings products somewhat than microfinance products by households. The primary data was collected from SHG respondent, to data collected interview scheduled was used, Methodology Logistic regression this phenomenon is explained by the fact that microfinance products, and especially loans, from formal microfinance institutions very useful the households demand. Because financial institution (MFs) following of very strict regulation have access microfinance. This study first presents evidence on the observed observable fact in the microfinance access. Second, it analyses the microfinance access so as to understand the determinants of the microfinance from formal sources versus SHGs sources. The results reveal the microfinance access of the loan, level of education, and agricultural purpose, employment, the geographical location, and distance of MFIs where households live and as factors influencing the choice for microfinance finance sources.
\end{abstract}

Keywords

- Microfinance;

- Self help group

- Development economics

- Rural development

- Access to credit;

\section{Introduction}

Microfinance is made up of a set of small size financial products which include savings, credit and insurance, and which suit people with low incomes who were at first excluded from the classic or formal banking system (Soulama, 2005). According to Cull, Demirguc-Kunt, and Murdoh (2009), the argument that microfinance institutions should seek profits has an appealing "win-win" resonance, admitting little trade-off between social and commercial objectives. Irrespective of the renewed emphasis on the financial systems approach, over the years, many Micro Finance Institutions (MFIs) have developed a range of services to address the requirements of the poor, such as the Income Generation for Vulnerable Group Development (IGVGD) programme of BRAC, Bangladesh. Despite the widely held belief among strategy makers that microfinance has a relatively small impact on poverty at macro level, some recent studies have shown its significant effect on poverty using household survey data. Microfinance products are provided by the intermediation of a multitude of institutions which vary according to size, the degree of organization and the legal status, and include NGOs, associations, mutual insurance companies/cooperatives, limited companies, banks, financial institutions, but also more informal and unregulated institutions such as tontines, usurers, change keepers, loans between friends, etc. (Soulama, 2005, www.lamicrofinance.org). For some years now, microfinance has been found a vital tool to eradicate poverty among the vulnerable by the provision of products and banking services similar to those delivered by classic institutions (Brau and Woller, 2004). Observations were made on the growth of these institutions all over the world. In fact, according to the report of the 2012 campaign published by the microcredit summit on December 31, 2010, there existed 3652 institutions that took care of about 200 million customers.

In spite of their recent development and strong proximity to the poor, it is important to note that formal microfinance institutions only bring a very partial answer to the poor households' need for finance. Nimal (2008) reveals that although microfinance institutions are present in Asia and the pacific regions, more than 300 million households undergo from the lack of access to financial products offered by the formal and semi-formal sector. In sub-Saharan Africa in 2008, the number of active borrowers and savers in percent of population living under national poverty line has reached a rate of penetration of about $3 \%$ for credits and $5 \%$ for savings (MIX 
and CGAP, 2010). These rates confirm the irony observed around microfinance today which is the preference of households for savings products, in comparison to loans (Meyer, 2002).

Therefore, however, some studies have shown that MFIs have not reached the poorest of the poor in Asian countries (Weiss \& Montgomery, 2005) or in Bolivia (Mosley, 2001). On Indian SHGs specifically, impact studies consist of the Puhazendhi and Badataya study (2002) commissioned by NABARD (India's rural development bank) with 115 members and three states. The study measured impact by computing the percentage difference of the means of members' variables pre and post SHGs membership. Clearly, this type of analysis does not account for any changes in observable characteristics or broad economic changes through a control group. Due to inappropriate corrections for selection bias, Tankha (2002) states, "their findings cannot be careful to be decisive or even convincing."Nevertheless, this Puhazendhi- Badataya (2002) study has had much policy influence, quoted by many sources and most recently by the RBI (2008) there seems to be a need to understand the behavior and preferences of the poor in terms of financial services (Matin et al., 2002). Given the often informal nature of the financial services used by the poor, such an analysis requires integrating the presence of social networks and social capital not only as a source of choices of credits but also as an explanatory factor of the choice. In developing countries, networks are made up of the community and ethnic groups. The first network generally constitutes a source for competitive credit. Considering ethnic network analysis, studies on their interaction with the credit market are scarce. Some research documents examine the interaction between ethnic groups, credit and enterprises in Africa but they do not explore the diversity of the indigenous African population (Biggs et al., 2002, Fafchamps, 2000, Fafchamps, 2003 and Fisman, 2003). Azam et al. (2001) equally do not take into account this indigenous diversity. This paper tries to fill this gap, by including ethnic diversity in the indigenous Indian population in the analysis of preferences and use of financial instruments. The study focuses in the first place on estimating a model that explains what determines whether or not households in Tamilnadu in India make use of microfinance loans.

\section{Literature review}

Micro-finance rations empirical analysis explanation of the Access formal sources. In fact, according to Stiglitz and Weiss (1981), the presence of problems of asymmetries of information (adverse selection and moral hazard) at the level of financial markets and the problems of enforcement of contract lead to credit rationing through the formal sources. Chung (1995) and Mushinski (1999) shamika Ravi et al (2011) showed that heavy transaction costs in the formal sector can discourage some households to take loans. In such a situation borrowers need to consider informal sources as last resorts or as alternatives to the formal sector in developing countries. According to Kochar (1992), informal loans, especially those from friends and parents, would be less expensive as compared to the formal loans and therefore preferred by borrowers. Guirkinger and Boucher (2007) add to this that informal lenders have access to local information, allowing them to write down contracts that are less risky for borrowers. The relatively low information and transaction costs, the simplicity and flexibility in financial procedures ease access to low income persons.

The microfinance literature demonstrated how the problem of information asymmetry can be tackled by the use of social capital (Rankin, 2002, Gomez and Santor, 2001 and Besley and Coate, 1995). Social capital refers to the norms and networks that enable people to act collectively (Woolcock and Narayan, 2000). Fox (1996) defines social capital as a social organization, relationship of cooperation and reciprocity, networks and leadership that facilitate collective action. Social capital could be the degree of trust in government or other societal institutions (Fukuyama, 1995 cited in Okten and Osili, 2004), social cohesion, reciprocity and institutional effectiveness. Or as stated by Grootaert and van Bastelaer (2002a), social capital is broadly the set of institutions, the relationships, the attitudes, and values that govern interactions among people and contribute to economic and social development. This definition depicts closely the developing countries' situation. Social capital helps to correct the issue of incomplete information by ensuring default payments through social sanctions. Social capital can be a tool for the diffusion of information on the sources of finance and consequently will influence the different choices (Okten and Osili, 2004). This explains the inclusion of variables like ethnic groups and religious adherence further in this model. In the same way, their presence can constitute a non-negligible competitor for the MFIs.

At the empirical level, some authors think that it is important to make the distinction between access and participation to loan (Zeller, 1994 and Diagne and Zeller, 2001). Access to microfinance is an essential trend concerning the supply of credit, due to the fact that the lender decides on who can borrow or not. Participation is a phenomenon linked to demand. A household has access to a certain source if it can in principle borrow from this source. The household participates if it in fact borrows from this source. Therefore, a household can have access and choose not to borrow. Taking into account this distinction, the decision to choose one particular source of finance is done from an analysis of the demand for credit expressed by households and that is the move toward developed in study. 


\section{Objective of the study}

To analysis Microfinance Accessibility and Households Improvement jawadhu hills of Tiruvannamali District in Tamilnadu

\subsection{Hypothesis}

Ho: microfinance Accessibility have not Households Improvement Jawadhu hills of Tiruvannamali District

\subsection{Methodology the Household access of microfinance: empirical approach}

An analysis of households decisional choices in the credit market are usually carried out using discrete choice models (Zeller, 1994, Duong and Izumida, 2002 and Nguyen, 2007 ). In fact, according to Atieno (2001), it is impossible to identify a program for the demand for loans using an amount of observed loans since this only reflects the existing supply. The access microfinance function can only be interpreted from the decision to participate by the borrower, that is the decision to borrow or not to borrow and from which sector. The study using primary data though interview, econometric model logistic regression used,

Zeller (1994) used a univariate probit model to estimate factors determining the borrowing decisions of individuals, from the point of view of their participation in the formal or informal credit market in Madagascar. The author treats market segments individually to identify the similarities and differences between the sectors in terms of demand for credits and their rationing. Nguyen (2007) also separates the sources of loans while expecting that the determinants of credit participating be different as the eligible requirements are different between sources.

Assuming that the household is rational in the sense that it makes choices that maximize its direct utility subject to constraint on expenditure, it is possible to derive an indirect utility function (Maddala, 1983). We define an underlying latent variable $y^{*}$ to denote the indirect utility level associated to the direct utility $y$. The observed variable $y$ is defined as:

Equation.

$y=1 \quad$ if $y^{*}>0$

$\mathrm{Y}=0$ otherwise

However, there are many errors in this maximization because of imperfect perception and optimization, as well as the inability to measure exactly all relevant variables. McFadden (1974a) suggested using a random function where the random term comes in an additive manner. Consequently, this indirect utility function $y^{*}$ will be written as follows:

$y^{*}=\beta x_{1}+\varepsilon_{1}$

where $x_{1}$ is a vector of observable attributes specific to the household; $\varepsilon_{1}$ is the random component of utility that represents the unobserved household $i$ 's idiosyncratic taste for choosing a source. It is assumed to be independently and identically distributed.

Choice of the source of borrowing is a two-step process which requires that households demand a loan at the first stage, and at the second stage they choose the source where they want to borrow. Since the second stage is a conditional on the first stage, it is likely that the second stage sample is non-random, which could create a sample selection bias. Indeed, Nagarajan et al. (1995) think that estimates of loan demand or choice of credit source are often biased because they use models that do not adequately correct for selectivity bias. Therefore, it is important to correct for this sample bias in order to obtain consistent estimates. In our case, it is believed that the decisions of choosing a source of borrowing and that of expressing a demand of loan are correlated (both decisions are binary). In effect, the data set specifies a binary variable that identifies the observations for which the dependent is observed/selected or not observed.

The underlying structural framework is a household access model with utility maximizing households, who demand credit (access $=1$ ) if a loan is expected to increase utility, and they do not access microfinance (have not access $=0$ ) in the contradictory case.

The dichotomous microfinance access selection equation is given by:

Equation

$d= \begin{cases}1 & \text { if } d^{*}>0 \\ 0 & \text { otherwise }\end{cases}$

The latent equation is given as follows:

Equation

$d^{*}=\delta x_{2}+\varepsilon_{2}$ 
The outcome dependent variable $y$ is observed only if $y^{*}>0$ and $d=1 \mathrm{y} *>0$ and $\mathrm{d}=1$. In other words, the dependent equation can be written as follows:

Equation

$y= \begin{cases}1 & \text { if } y^{*}>0 \text { and } d=1 \\ 0 & y^{*} \leq 0\end{cases}$

Where the latent equation for outcome equation is

Equation

$y^{*}=\beta x_{1}+\varepsilon_{1}$

It is assumed that the latent errors are bi-variate normal and independent of the explanatory variables. The probit model with sample selection can be expressed as follows:

Equation

$y_{i}^{*}=\beta x_{1}+\varepsilon_{1}$

$y_{i}=\left\{\begin{array}{l}1 \text { if } y_{i}^{*}>0 \text { and } d=1 \\ y_{i}^{*} \leq 0\end{array}\right.$

$d_{i}^{*}=\delta x_{2}+\varepsilon_{2}$

$d_{i}=1$ if $d_{i}^{*}>0$ and 0 otherwise

Heckman (1990) has shown that selection bias can be overcome by including the inverse Mills ratio from the sample selection equation in the equation of interest. In this approach, the selection into the sample of those who demand credit is first modeled. Then, the inverse Mills ratio (lambda) from this regression is incorporated into the equation of interest.

We also encounter a problem of endogeneity of some explanatory variables. In fact, information on interest rates which represent the prices of loan from each source is missing in the data set. Since prices and income are the key variables explaining the demand for credit, the non-inclusion of the prices variable could create a correlation between the variable income and the error term. That could lead to an endogeneity bias, making the estimator inconsistent. Cited in Wooldridge (2001), provide a simple test to verify endogeneity in the case of a binary model.

Finally, to test hypotheses in line with the previous section, we specify the access demand of loan as a linear function of household characteristics including income, gender of household head, age of household head, number of household members, religion, education level of the household head, geographical location, and socio economic group of the household head, etc.

Econometric model

Equation such below:

$\mathrm{MF}=\beta_{0}+\beta_{1}$ GEND $+\quad \beta_{2}$ RSAGE $+\quad \beta_{3} \quad$ MARRIED $+\quad \beta_{4}$ UNMARRIED $+\quad \beta_{5}$ WONLAND $+\beta_{6}$ LIVESTOCK $+\beta_{7}$ CULTIVA $+\beta_{8}$ AFTASSETV $+\beta_{9}$ DEPENDRO $+\beta_{10}$ HOUSEHSIZE $+\beta_{11}$ SELFEMPLOY + $\beta_{12}$ NOEDU $_{\mathrm{i} 1}+\beta_{13}$ PSEDUCATION $_{\mathrm{i} 2}+\beta_{14}$ HSEDUCATION $_{\mathrm{i} 3}+\beta_{15}$ INCOME $\beta_{16}$ LOCAT $+\beta_{17}$ DISTBUS $+\beta_{18}$

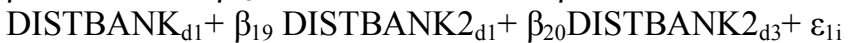

MF denotes the loan access equation, GEND denote the sex of respondent, RSAGE denote the age of respondent, MARRIEDST denotes the marital status of the household head, HHEDU denotes the household head education, TYPHOUSE denotes the types of house, WONLAND denotes the respondent have own land, LIVESTOCK denotes they have livestock, DEPENDRO denotes the numbers child dependent of household head, AFTASSETV denote assets values of the respondent, FAMILYTYP denote family types of respondent, SAVING denote whether household head have the savings, PURPOSBRO denotes the household does not plan to extend its activity, NOEDU denotes the level of no education, PSEDU denotes the household head primary education, HSEDU denotes high school or above, H_INCOME denotes household income level, LOCAT denote the geographical location, DISTMARK denotes the distance of household to market, DISTBANK denotes the house to bank distance, DISTBUS denotes the household to bus stop and $\varepsilon_{i 1}$ denotes the error term assumed to be normally distributed.

\subsection{Data}

Multi-stage random sample technique followed first stage chosen district, second stage selected taluk, than find out two panchayets it was covered 15 villages Primary data was collected through a survey interview used structured questionnaire, which include characteristics of the sampled households interview conducted in 2012 by the researcher, and it is part of research work. The research unit is the household and the people who live in it. The 400 households Living Standards interview is a district wide, the household interview through 
questionnaire with modules covering numerous aspects of living standards. The interview contains detailed information on microfinance access households from Tiruvannamalai District. Here gathering data on education, and employment status of household members, household economic activities, income and expenditure, household size and housing, borrowing and lending activities. It covers 6160 households living in Tiruvannamalai district. Out of 6120 households interviewed 400 households head respondents, including beneficiaries 260 and non beneficiaries 140 sample. They represent $17.9 \%$ of the overall sample. This sample is composed of those who have access for and who have not access beneficiaries, those who have female and male, and those whose application has been refused. Table 1 gives a descriptive of this sub-sample of households needs a microfinance loan and presents the constructed variables' summary statistics.

Table 1 Descriptive Statistics

\begin{tabular}{|c|c|c|c|c|c|}
\hline & $\mathrm{N}$ & Minimum & Maximum & Mean & Std. Deviation \\
\hline MICROFI & 400 & .00 & 1.00 & .6500 & .47757 \\
\hline GEND & 400 & .00 & 1.00 & .8150 & .38878 \\
\hline RSAGE & 400 & 20.00 & 57.00 & 37.2800 & 8.04135 \\
\hline UNMARRIED & 400 & .00 & 1.00 & .0550 & .22827 \\
\hline LIVESTOCK & 400 & .00 & 1.00 & .8825 & .32242 \\
\hline CULTIVA & 400 & .00 & 1.00 & .9150 & .27923 \\
\hline BEASSETV & 399 & 32000.00 & $1.12 \mathrm{E} 5$ & $5.0632 \mathrm{E} 4$ & 12879.96544 \\
\hline DEPENDRO & 400 & .00 & 6.00 & 2.4825 & .89257 \\
\hline HOUSEHSIZE & 400 & 2.00 & 14.00 & 4.8925 & 1.73738 \\
\hline SELFEMPLOY & 400 & .00 & 1.00 & .1450 & .35254 \\
\hline NOEDU & 400 & .00 & 1.00 & .1975 & .39861 \\
\hline PSEDUCATION & 400 & .00 & 1.00 & .1375 & .34481 \\
\hline HSEDUCATION & 400 & .00 & 1.00 & .1425 & .35000 \\
\hline INCOME & 400 & 7000.00 & 30000.00 & $1.6020 \mathrm{E} 4$ & 3641.11856 \\
\hline LOCAT & 400 & .00 & 1.00 & .9375 & .24236 \\
\hline DISTBUS & 400 & .00 & 1.00 & .2650 & .44189 \\
\hline DISTBANK & 400 & .00 & 1.00 & .0475 & .21297 \\
\hline DISTBANK1 & 400 & .00 & 1.00 & .1150 & .31942 \\
\hline DISTBANK2 & 400 & .00 & 1.00 & .8600 & .34742 \\
\hline
\end{tabular}

Source: authors' calculations

\subsection{Variables in the Equation}

MF access denotes the access microfinance loan equation, Most of respondent female respondent, remaining respondent male, Average age respondent 37.55 year old, majority of them (81.5 percent) of female respondent, 94.5 Percent of respondents marital, rest of them unmarried household head, LIVESTOCK they have livestock 88.2, percentage of respondent, child dependence ratio 2.4 numbers of household head, the level of informal sign 19.7 percent, 13 percent the household head primary education, HSEDU 14 percent high school or above, House holed income level was Rs.160,20, only 14 percentage of the respondent engaging self employment activity, LOCAT 93.7 percentage the geographical location, DISTMARK denotes the distance of household to market, DISTBANK2 majority of respondent house in hills area to bank distance 30 above kilo meter.

Figure 1.Age level of the respondent microfinance and non-access respondents.

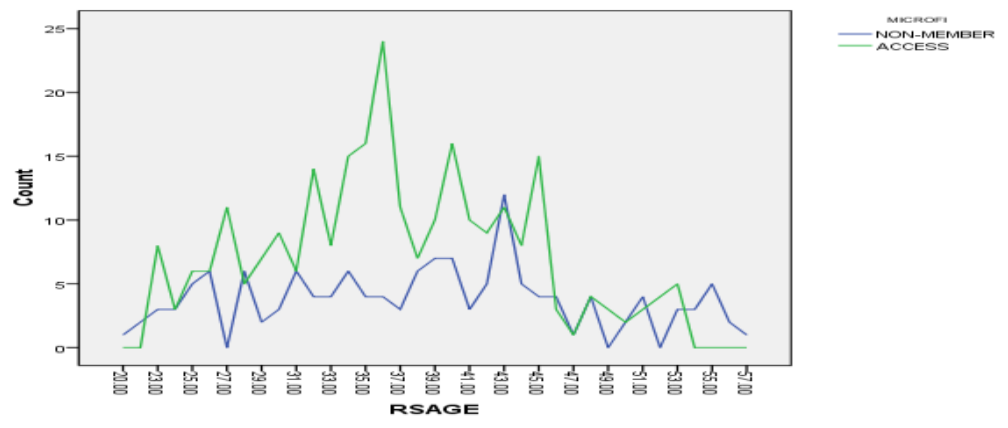

Microfinance access age level of respondent minimum age 20, maximum age 57 year old, so most of respondent age 35 to 40 year old access microfinance, they involving self employment activity. They need financial resource from MFIs. 
Table 2

Logistic regression estimated the determinants of choosing microfinance

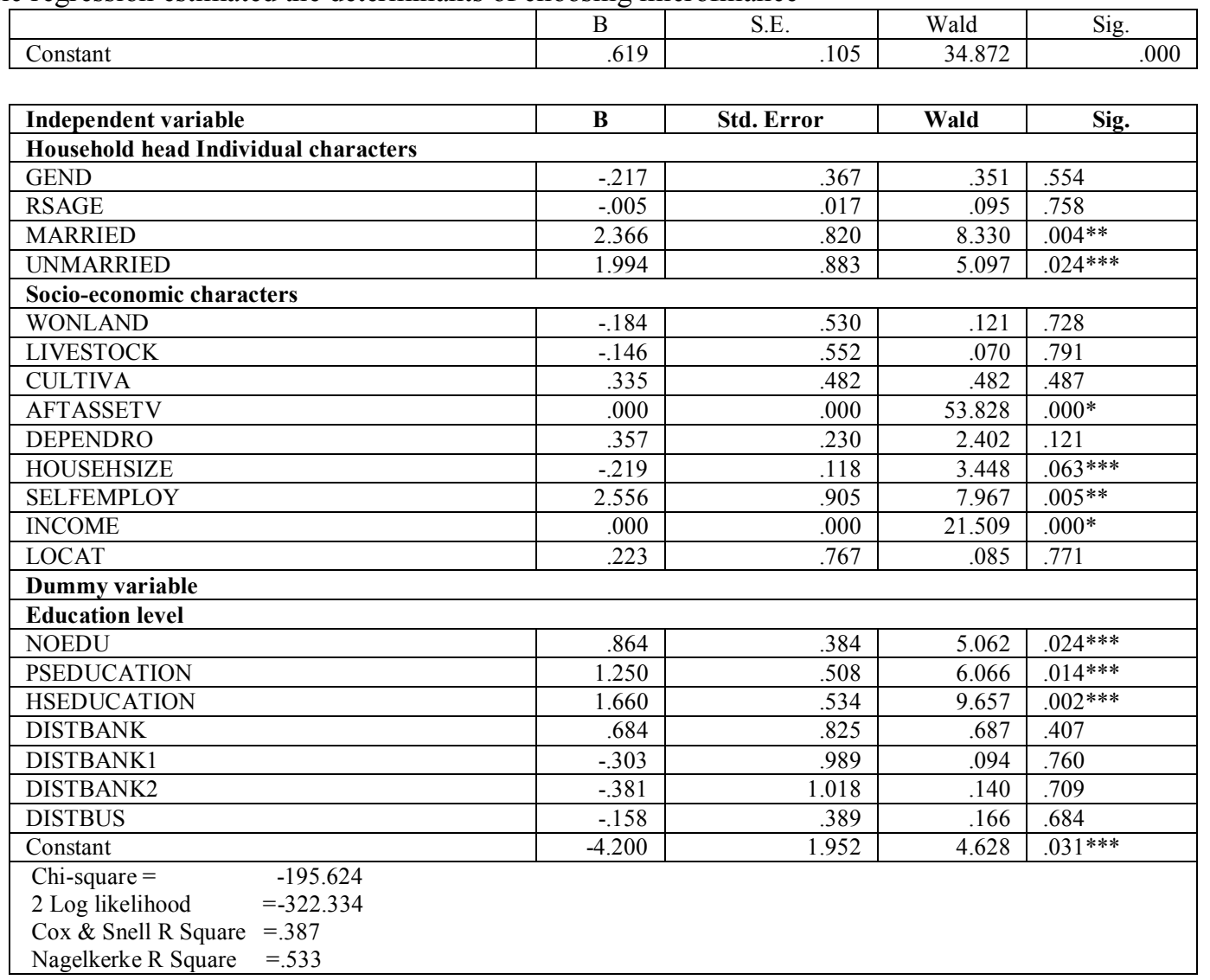

Source: own computation from 2013 Survey Data.

$* * *$ Significant at $1 \%$.** Significant at $5 \%$. Significant at $10 \%$.

Table. 2 showing Logistic regression made analysis household accessibility Based on the estimated results, total 20 variables are found to have significant influence on households' accessibility to micro finance, it was overall 83 percentage model correct. Include GEND (-), RSAGE (-), MARRIED (+), UNMARRIED (+), WONLAND $(-)$, LIVESTOCK (-), CULTIVA $(+)$, AFTASSETV $(+)$, DEPENDRO $(+), \quad$ HOUSEHSIZE $(-)$, SELFEMPLOY $(+)$, NOEDU $(+)$, PSEDUCATION $(+)$, HSEDUCATION $(+)$, INCOME $(+)$, LOCAT $(+)$, DISTBUS (-), DISTBANK(-), DISTBANK1(-), DISTBANK2(-). out of 20 variable 9 variables are statistically significant.

The significant positive signs on MARRIED, UNMARRIED, AFTASSETV, SELFEMPLOY, INCOME, NOEDU, PSEDUCATION, and HSEDUCATION variables may be explained from the perspective of capital requirement. High-income households tend to have more investment opportunities, leading to stronger potential need for microfinance support. High-income households may also be more confident in repaying loans if they access. Therefore, they are more inclined to access microfinance. Similarly, the probability of accessing microfinance can be significantly improved when households get involved in self-business apart from agriculture production because of the higher capital requirement for investing in self enterprises. By the same token, households with members self business have greater need of microfinance access for off-farm investment and thus have a higher probability of accessing microfinance. Households with members working as local craft goods may also access micro-finance more easily due to their presumed good relationship with local financial institutions such as tribal co-operative society and nationalized bank.

On the contrary, the significant negative signs on HOUSEHSIZE variables imply that households that are less budgets constrained or have surplus funds under their own control would be less likely to access microfinance.

The demographic profile of the 400 respondent household indicates that the average age of a household head is 37.28 years and about $84.63 \%$ of them fall in the economically active population (ages 20-57). The majority of household respondent (80.2) have no education. Approximately $13.8 \%$ and $14.2 \%$ of them have primary school education and high school education respectively. The socio economic categories define the 
broad sector of employment of the household head. The statistics reveals that the majority of households heads work in the agriculture activity laborer sector for the choice of for formal institutions, and the agricultural sector for formal loans. The majority of the household heads are married, which is a sign of household stability.

The average household size in the entire sample is 4.89 persons per household. Concerning the income, the average value of income for formal sources is inferior to those of the informal sources suggesting low income households prefer demanding loans from the formal sources. The asset variable is a combination of the asset data which are all dummy variables, indicating whether households own a particular asset or not. Principle component analysis has been used to create the asset index, to proxy wealth and capture ownership of tangible assets. The assets considered are consumer durables goods. Ownership of these assets determines the choice of formal source since those assets could be used as collateral respectively distance parameter take dummy negatively significant associated accessing finance source DISTBUS (-), DISTBANK (-), DISTBANK1 (-), DISTBANK2 (-). Because distance to financial institution office very long in order to access microfinance (it has more $30 \mathrm{~km}$ )

Social capital or social networks play an important role in the Ivorian context. In line with the definition by Grootaert and van Bastelaer (2002a), social capital represents the institutions, relationships, attitudes, and values that govern interactions among people. Tribal backgrounds play an important role in these variables. Within these groups, potential borrowers share cultural similarities, facilitating access to microfinance to their members (Azam et al., 2001).

\section{Empirical results of borrowing sources}

As stated earlier Logistic regression approach is used to estimate the determinants of choosing a microfinance program. Before proceeding to the regression analysis, let us analyze the stated endogenous problem. As stated earlier, Tiruvannamali district approach allows making a simple test on the residuals from income regression. This test reveals that income is correlated with the error term in the access equation. Concerning the demand of loan equation, the convectional Wald test statistic is significant at $1 \%$. It rejects the null hypothesis that all coefficients are zero. Knowing the sign of the parameter is enough to determine whether the variable has a positive or negative effect on the access equation.

The following variables have been found relevant to explain the demand for a loan: income, owning land, having an own business, the household size, having no development project, and geographical location. The effect of income is positive and significant for demanding a loan. That demonstrates that a household demands a loan when its income is higher. Owning land increases the probability of demanding a loan. The explanation is that the land could be used as collateral by the household.

In the second step of the estimation, we try to determine the factors influencing the choice of formal versus informal sources. Again, the conventional Wald test statistic is significant at $1 \%$, rejecting the null hypothesis that all coefficients are zero. The predicted probability of choosing formal source is $11.56 \%$. That confirms the fact there is preference for informal sources in Cote d'Ivoire (Azam et al., 2001).

The following variables have been found relevant to explain the choice of formal source. Income has a negative effect on the likelihood that a formal source is chosen. Thus, financial sources of credit are preferred by low income groups. This is one of the main variables in our analysis, and result as an indication microfinance may help solve some part of the market failure in the financial sector in Tamilnadu. Low income households who will not be able to get a loan in the formal sector do get access to credit through the informal sector. This is particularly relevant in combination with the result for the loan size. The size of the loan is positively and significantly related to the probability of choosing the formal finance program. Indeed, the probit results display a positive and significant effect of the loan size for the alternative of formal source. That supports the presumption in the literature that informal institutions are far more effective at financing small borrowers than the formal institutions. Therefore, when the loan size is larger the household will choose formal sources. The higher transaction costs that are typically related to borrowing from formal sources may in the case of larger loan sizes become relatively smaller. The importance of personal wealth is confirmed here by the positive effect of the variable asset index, proxy of wealth, on the choice of the formal sources. In addition, the age of the household head raises the probability of borrowing from formal sources.

The effect when the household head lives in western rural forest and rural savannah comparatively to Abidjan is negative on the probability of borrowing from formal source. In fact, households living in such regions have difficulties to access to facilities, higher transaction costs and as such they do not choose formal institutions. This result is in line with the unequal distribution of MFIs on the whole territory, as stated by the national commission of microfinance (NCM, 2005). The magnitude of these effects when the household head lives in western rural forest and rural savannah are a decrease of $6.7 \%$ and $6.3 \%$ respectively. This result corroborates Guirkinger's (2008) finding and Swain's (2002) finding that an area where the borrower lives has an impact on the choice of source of access. 


\section{Conclusion}

Understanding the socioeconomic factors influencing the determinants of households' preference of microfinance program is useful for outlook policy designs, as it can give an indication of how well the microfinance access performs its function. Formal sources of loan co-exist in the market, with informal sources providing lower transaction costs. Because of information asymmetries, microfinance rationing may exist in the market, and transaction costs may be high. This may especially affect low income households, who may have a higher preference for small loans and thus face disproportionately high transaction costs in the formal financial sector.

This study attempted to clarify the role of microfinance in solving market failure by testing the impact of three variables on the source of microfinance. These variables were the household income, the size of the loan, and social capital, which was measured by tribal community background. It was in fact found that low income households tend to have a preference formal source of financial source, and smaller loans are also performed through the informal sector. This confirms our hypothesis that informal loans through microcredit institutions have a particular role to play in the financial sector in Tiruvannamali district. We also found that the choice of source of microfinance it is really promoted household economic and social status, depends in distance networks the source of loan.

Thus, we conclude that microfinance institutions very important role to play in the economy of developing countries. In the descriptive work that preceded the statistical analysis, it was also found that microfinance institutions in Tiruvannamali district collect a much larger amount in savings than what they give out in loans. Also institution will provide more loans, it may reduce rural poverty and microfinance institution open for mountain area it better access household. This is an interesting feature that demands further theoretical and empirical work to clarify the exact role of microfinance in developing countries. Indian policy maker provide institutional facility very near to household.

\section{References}

[1]. Atieno, R. (2001).Formal and informal institutions' lending policies and access to credit by small-scale enterprises in Kenya: An empirical assessment. Nairobi, Kenya: The African Economic Research Consortium.

[2]. Puhazendhi, V., \& Badataya, K. (2002).SHG-bank linkage programme for rural poor-An impact assessment. Mumbai: NABARD.

[3]. Reserve Bank of India (2008).Rangarajan committee on financial inclusion.Mumbai: RBI.

[4]. Sharma, S. (2005). Factor immobility and regional inequality: Evidence from a credit shock in India. Mimeo, Yale University, Department of Economics.

[5]. Tankha, A. (2002). Self-help groups as financial intermediaries in India: Cost of promotion, sustainability, and impact. The Netherlands: ICCO Study

[6]. Ayyagari, M., Demirguc-Kunt, A., \& Maksimovic, V. (2008). Formal versus informal finance: Evidence from China.World Bank Policy Research Working Paper Series 4465.

[7]. Ben-Akiva, M., \& Lerman, S. (1985).Discrete choice analysis: Theory and application to travel demand. Cambridge, MA: MIT Press.

[8]. Brau, J. C., \&Woller, G. M. (2004). Microfinance: A comprehensive review of the existing literature.Journal of Entrepreneurial Finance and Business Ventures, 9, 1-26.

[9]. Cheng, E. J. (2006). The demand for micro-credit as a determinant for microfinance outreach-evidence from China. Paper presented at ACESA Annual Conference on 'Emerging China: Internal Challenges and Global Implications. Melbourne, Australia, 13-14 July.

[10]. Diagne, A. (1999).Determinants of household access to and participation in formal and informal credit markets in Malawi. Food consumption and nutrition division discussion paper 67, Washington, DC: International Food Policy Research Institute.

[11]. Diagne, A., \& Zeller, M. (2001).Access to credit and its impact on welfare in Malawi. Research Report 116. Washington, DC: International Food Policy Research Institute.

[12]. Kuppusamy.L and J.Srinivasan (2011) microfinance and poverty eradication: a special reference in Vellore district of Tamil Nadu, Macmillan publication, International conference volume, Delhi.

[13]. Du, X. S. (2004).Attempts to implement micro-finance in rural China. Organisation for Economic Co-operation and Development (OECD) - Centre for Co-operation with Non-members, Rural Finance and Credit Infrastructure in China, Paris: OECD Publications. pp. 271-27(2), 419-430.

[14]. Jia, X. P., Heidhues, F., \&Zeller, M. (2007). Taking the hands off the rural credit market: An evidence from China. Studies on the Agricultural and Food Sector in Central \& Eastern Europe, 39, 164-180. X. Li et al. / Journal of Asian Economics 22 (2011) 235246245

[15]. Klein, B., Meyer, R., Hannig, A., Burnett, J., \& Fiebig, M. (1999). Better practice in agricultural lending, Agricultural Finance Revisited (AFR no. 3). Food and Agriculture Organisation of the United Nations (FAO).

[16]. Maddala, G. S. (2001). Introduction to econometrics. Chichester, NY: John Wiley.

[17]. Mohamed, K. (2003).Access to formal and quasi-formal credit by smallholder farmers and artisanal fishermen: A case of Zanzibar, Research Report 03.6. Paper commissioned by the Annual Microcredit Summit Campaign, Dar es Salaam, Tanzania: Research on Poverty Alleviation (REPOA).

[18]. National Statistic Bureau of China (NSBC). (2008).Statistical year book available at:http://www.stats.gov.cn/english/, last accessed September 20th, 2007.

[19]. Train, K. (2003). Discrete choice methods with simulation. UK: Cambridge University Press.

[20]. Zeller, M. (1994). Determinants of credit rationing: A study of informal lenders and formal credit groups in Madagascar. Journal of World Development, 22(12 